\title{
“SHE HAD 'BALLS”": ISLAMIC LIBERALISM AND THE MODERN WOMAN IN A CONTEMPORARY MALAYSIAN FICTION IN ENGLISH
}

\author{
Bernidick Bryan P. Hosmillo
}

English Department, Ateneo de Manila University, Philippines

ichthus_10@yahoo.com

\begin{abstract}
The paper wants to dissect the plurality of contemporary Malay society by focusing on the construction of woman sexuality as charged with an amalgam of Islam Parochialism that is seen as a restrictive sociopolitical mechanism and (de)concentrated modernization that decentres religious functions in contemporary Malay society and uses instead a rather 'filtered' Islam as colour for the contours of life. Further, the paper underscores the fictive, yet real advances of the Malay woman in terms of critical consciousness and beauty manifested in cultural materialism as both are seriously equated to power. The woman, however, with all the intellectual and material elevation intervenes with (masculine) sexualisation. Hence, the paper capitalizes the necessity to examine the complexities of masculine sexualisation, as fortified by Western modernity, which is a process of recognizing the feminine presence that inevitably generate erotic desire to sexual fantasy that ultimately constructs the woman. The paper's major thrust is to reconceptualise the notion of power anchored in the ideological framework of its polysemous nature. Such progressive elucidation of the concept creates tension between empowerment and domination which is a relevant concern in feminist politics and interpretations in that the specific implication of such reconceptualization is the object of becoming not oppressors, but of becoming liberated that in the discourse of Malayness is largely problematic as it is always perceived to be antithetical to revitalization of Islam through authentic Malaysian Literature in English for 'liberalism' in this case, is associated with the rupture of women's sexuality.
\end{abstract}

Keywords: Islam, modernity, Karim Raslan, liberalism, female sexuality

\begin{abstract}
ABSTRAK
Makalah ini ingin membedah pluralitas masyarakat Melayu kontemporer dengan berfokus pada pembangunan seksualitas perempuan yang diisi dengan campuran dari parokialisme Islam yang dipandang sebagai mekanisme sosial-politik yang membatasi dan (de) modernisasi terkonsentrasi yang mebuat fungsi agama terdesentralisasi dalam masyarakat Melayu kontemporer dan sebagai gantinya menggunakan agak Islam yang 'disaring' sebagai warna untuk kontur hidup. Selanjutnya, artikel menggarisbawahi, kemajuan fiktif namun nyata perempuan Melayu dalam hal kesadaran kritis dan keindahan diwujudkan dalam materialisme budaya karena keduanya disamakan serius dengan kekuasaan. Wanita, bagaimanapun, dengan semua campur ketinggian intelektual dan material dengan seksualisasi (maskulin). Oleh karena itu, artikel ini mengkapitalisasi kebutuhan untuk memeriksa kompleksitas seksualisasi maskulin, seperti dibentengi oleh modernitas Barat, yang merupakan proses mengenali kehadiran feminin yang pasti menghasilkan keinginan erotis hingga fantasi seksual yang merupakan konstruksi akhir pada wanita. Isu artikel ini adalah untuk melakukan rekonseptualisasi gagasan kekuasaan berlabuh dalam rangka ideologis alam polysemous nya. Penjelasan progresif konsep ini menciptakan ketegangan antara pemberdayaan dan dominasi yang merupakan keprihatinan yang relevan dalam politik feminis dan interpretasi bahwa dalam implikasi tertentu konseptualisasi tersebut adalah objek bukan menjadi penindas, tetapi menjadi dibebaskan bahwa dalam wacana KeMelayuan sebagian besar bermasalah karena selalu dianggap bertentangan dengan revitalisasi Islam melalui Sastra Malaysia otentik dalam bahasa Inggris untuk 'liberalisme' dalam hal ini, terkait dengan pecahnya seksualitas perempuan.
\end{abstract}

Kata kunci: Islam, modernitas, Karim Raslan, liberalisme, seksualitas perempuan 


\section{INTRODUCTION}

On the $2^{\text {nd }}$ day of a conference organized by a Catholic university in Central Java, Indonesia, the writer met a Malay woman (therefore, Muslim) who dismissed a coarse explanatory notes about the pervasive presence of Femina and Indonesian editions of Cosmopolitan magazines she saw in Jakarta. Her unequivocal disgust had nothing to do with the scholar who presented a study on those magazines, but with the 'exploitation' of women those magazines perform. What interests me in the comment of this character was her infectious 'passionate' observation that made a significant veiled feminine part of the audience share her criticism. Such passionate conceptual development on the idea that women's magazines basically erupts the entire movement of progressive women emancipation that, to Slavoj Zizek (2008), 'inexorably function as a lure which prevents us from thinking'.

As a beginning scholar from a very diversified, anomalous, and almost shapeless fanatic society, uncovered women are not atypical in cultural representations of the public like television and magazine. But to hear a veiled woman in a passionate cry not wanting to strip off her burqa (woman's head-to-foot veil) under a violent sun is very peculiar. Such kind of subjectivity arouses my attention in that it debunks a huge scholarship (Western at that) which often equate muslim women's clothing to barbarism and impediment to liberalism. Just like the Malay woman I met in the conference, Carmody (2010) claims that "[l]iberalism, like all other big-picture political discourses, creates a certain kind of subject, one that is free to fully participate in the capitalist system." Thus, liberal ideology, as it always extends freedom to 'unfree' populations, becomes hegemonic and rather impedes the movement toward rights-based utopia. Such kind of ambivalence is the central concern of this paper and it is my hope that certain Malay subjectivities (not only by woman, but also of Others) shall be scrutinized dispassionately.

In a non-fictional prose entitled 'Anti-Islam and all that Jazz' in his second published book, Salleh Ben Joned (1994) criticized a type of thinking about literature in Malay critical writing. His attack was chiefly pointed to the ideal that Encik Affandi articulated against Professor Muhammad Haji Salleh of Universiti Kebangsaan Malaysia (National University of Malaysia). After a publication of the UKM's professor's inaugural lecture called Puitika Melayu (Malay Poetics), Encik Affandi averred that the UKM professor heavily worshipped the West for using Western literary theories to formulate the conceptual basis of traditional Malay literature. Moreover, Encik Affandi speculated that the professor was very anti-Islamic. The dispute between the two giants in Malay literary theory is just consequential to a movement that started to dominate not only the religious activity of Malaysia, but also its politics and causal to more intricate and problematic debates like 'What is the true Malay concept of literature?' or 'How to appropriate non-Malays' involvement in Bahasa Malaysia writing?' Before I discuss these very amorphous tensions in Malay/sian Literature, I believe that it is very necessary to elucidate the context of Islamic Revivalism which exacerbates and to some extent even ignite these forms of debate.

Although Southeast Asia is the most populous Islamic region, within Islamic studies the region has been perceived as an image at the margins and so has gained only a limited attention. Vincent J.H. Houben (2003) believes that the special characteristic of Sunnite Islam in Southeast Asia is portrayed through its mysticism. Mysticism facilitates the fusion of Islamic with pre-Islamic cultural forms which is usually a route of Malay literary theorists in conceptualizing Malay literary theory (Ben Joned, 2004). Malaysia is one among several countries engaging in a systematic wave of Islamic resurgence or revivalism. A concomitant feature of the intense Islamization of the region is the change in lifestyle in that Malays are not to be engrossed in the material aspects of life anymore, but to share a common romantic nostalgia for a pristine and idealized Islamic past. 
Mohammad Abu Bakar (1981) historicizes in great detail the origins of Islamic resurgence in Malaysia telling that two groups were directly involved in the movement. The first was the Arabic and religious-educated group that urged the Malay populace to uphold the teachings of the Koran and the Hadith (Prophetic Tradition) after Merdeka (independence). This particular group operated through Islamic organizations namely Jamaat Tabligh (Lecture Group) and Darul Arqam (The House of Arqam) which began the spread of fundamentalist ideas at the grass-roots level. However, of the two, Darul Arqam seems to be more convincing because it was mainly composed of Malays and subscribed to diplomatic manner of propagating Islam. The second group responsible for the resurgence was primarily composed of educated students in English and Malay tongues.

The Angkatan Belia Islam (Muslim Youth Organization) was the most resounding active player in the entire process of proselytization providing basic platform for students to continue their dakwah (missionary) activities and propagating ideal shariah (Islamic laws) to the younger Malay generation vociferously. Generally, there are four characteristics of Islamic Revitalization operating in the context of Southeast Asia. Hussin Mutalib (1990) discusses these characteristics lucidly starting with the explication that the resurgence necessitated Malays to view Islam as al-adin, 'that is, a total, comprehensive, and all-encompassing way of life'. Malay secularists, who viewed Islam as a religion and hence separated from political fabric, perceived such a fundamentalist movement 'as an attempt to turn back the clock of progress' (Mohammad Abu Bakar, 1981). Secondly, muslims were encouraged to view Muslims in all geographical spaces within the framework of a global Muslim ummah (worldwide Islamic community). Thirdly, the revivalism nurtured Islamic fundamentalist values that all Muslims in the movement have to adhere fixedly.

Finally, the movement was characterized by an increase of establishment of movement-type bodies and 'some of these organizations have sought to transform their modus operandi from organizational activities into that of an Islamic movement' (Mutalib, 1990). In an enormous attempt to desecularize the socio-political fabric of modernizing Malaysia, ethnicity, class and sexuality are interactive in evolving ways within Malaysian society. For David Camroux (1996), the most important position is 'that being a Malay is for all intents and purposes the same as being a Muslim'. However, Christopher Furlow's (2009) analysis poignantly clarifies the question of Malay identity in the context of the revivalism. He discusses the issue by providing a framework established by the leading organizations that led an anti-British movement, the Malayan National Party (MNP) and the United Malay's National Organization (UMNO). MNP defines 'Malayness in terms of religion, race, and language. In contrast, UMNO used race, language, and custom'. Clearly, the place of Islam becomes the defining difference on the dynamic dialectics on Malay identity. In a technoscientific and multiethnic Malaysian society (Camroux, 1996), literature becomes a ruptured space-a fixed situation of fluid disputation and therefore a space whose function is amorphous. Salleh Ben Joned (1994) in an essay “The (Malay) Malaysian Writer’s Dilemma” questions pejoratively:

I feel, in fact, I know in my blood and my bone that I belong to tiny minority. Every time I sit down to write, I am bugged by these troubling questions: who am I writing for, in actual fact and ideally speaking? What am I supposed to be loyal to? In my pessimistic moments, I even wonder if I have any audience to write for; if the element of stubbornness in my notion of loyalty and fidelity had not condemned me to a no man's land.(page 48)

Salleh Ben Joned (1994) uses the term 'Malaysian' to denote two things: ideal and language. His works (specifically As I Please) would use the premise, a line in Koran that reads 'There is no compulsion in religion.' Definitely, he excludes himself from those writers who have developed a sense of compulsion to be proactively part of Islamic Revivalism. If religious choice is not served to a true Malay, for Salleh Ben Joned, a Malay also considers individual choice as part of his vocabulary, particularly language. Unlike traditional and conservative writers who are being continuously Islamized, he emphasizes the strengths and capability of English language and the Malay tongue to Malaysian Literature rather than restricting himself into the use of vernacular alone. In stark contrast, 
writers like Alias Ali, Ruhi Hayat, Keris Mas and Shahnon Ahmad contributed a lot not only in the creation of Malay fiction, but also in the massive movement of Islamic Revivalism. Keris Mas and Shahnon Ahmad were awarded the most prestigious literary award in Malaysia, i.e. Anugerah Sasterawan Negara (National Literary Award) in 1981 and 1982, respectively. For these authors, Islam is 'a conscious model for positive social sentiments in Malay villages (kampong) and as a symbol of Malay nationalism with the potential to refashion and improve modern Malaysia' (Banks, 1990).

Purposely, after committing to generate an Islamic Literature (as a large part of Islamic Revivalism), Shahnon Ahmad writings became didactic 'using pious Muslim to demonstrate the importance of Islam in the moral world of the Malay village' (Banks, 1990) that creates Islamic fundamentalist sensitivity and religious basis for his writings; the need to be righteous and morally upright. Interestingly, Harry Aveling (2000) dismisses that Shahnon Ahmad does not further illuminate the gender construction of womanhood...in that women 'for all their involvement...do not have power so much as they are implicated in the power of men'. Laurent Metzger (1991) shares the same conviction that 'women...in his novels...tend to play second fiddle, are dominated by their male counterparts and they accept such domination'. Malay fiction, as inclined by Islamic Revivalism or some scholars would call as Religious Nationalism, uses Islam as a language of control, thus ostensibly eliminating feminine discourse preserving phallogocentrism.

Malaysian Literature, on the other hand, not only resists some convention of uptight Malay fiction, but also and more importantly becomes a proactive strategy to understand/interpret Malay culture most particularly when Malay fiction fails to do so. Following the veins of Salleh Ben Joned is a bumigeois in the name of Karim Raslan. In 1996, he published a book comprising of eight short stories (Raslan, 1996). Karim Raslan has authored four books (Ceritalah: Malaysia in Transition, Ceritalah 2: Journeys through Southeast Asia, Ceritalaha 3: A Dream Deferred, and Heroes and other stories) all written in English. His avant-gardism on anathema (e.g. homosexuality) in his sole fiction collection has drawn an ambivalent critical response from scholars and writers. He spent 22 years of living and studying in the homeland of his English mother and went back to Malaysia after earning a degree from Cambridge University.

Just like Salleh Ben Joned, Karim Raslan not only uses the English language in writing because of his Western education and higher social status, but also largely because of his defiance and criticism to the nation's existing socio-political ideologies. Two short stories shall be analyzed in this paper for the purpose of confronting the dilemma of the modern Muslim (Malay) woman which is often 'slippery' in Malay discourse. Very interestingly, the two short stories (The Beloved and Sara and the Wedding) present women's liberal sexuality that to a great extent curtails patriarchal dominance, thus, emancipating the feminine.

This paper argues that the modern woman's sexuality in the short stories is deliberate, performative assumption with great emphasis on mind, body, and beauty. Furthermore, the selfauthored sexuality becomes 'real' when the feminine presence is erotically desired by the other which grandstands that sexuality is neither self-sufficient nor wholly contingent. It is also underscored in this paper that eroticism, as a political mechanism and manifestation of sexuality, is a challenge to masculine virility and to the concept of malay social order and not just a dislocated lust (nafsu) effected by modernization. Hence, sexuality of the modern malay woman, as it appears to potentially undermine Islamic umma (social and religious community) and the bangsa (nation), is always linked to larger social and political change. I situate the two short stories within the context of Islamic Revivalism and approach them using Davina Cooper's framework which is a disintegrative theory drawn from neo-Marxism, radical feminism, and poststructuralism. 


\section{METHOD}

Davina Cooper's framework (Cooper, 1995) centres around four key concepts: power, sexuality, the state and struggle. I have three main reasons why Cooper's framework is heavily useful in this paper. Firstly, her framework positions on the premise that 'sexuality, as a disciplinary structure, identity and culture shapes state form and practice' (1) which is totally how the texts of Karim Raslan, as this paper maintains, works. It is a representation of structured sexuality that shapes the state. Secondly, her framework focuses on very important matters of this paper like the notion of power in Malaysian Literature in English. The concept is usually clarified in ambiguous terms whether it is present or not, but not necessarily elucidating the characteristics of the present power. Cooper's framework has a conscious effort to regard this special concern. Finally, the framework responds to questions I would like to give an answer in this paper, e.g. poststructuralist feminism would assume in particular that the concept of power is inevitable, does it necessarily follow that domination too is? So is inequality?

The paper's major thrust is to reconceptualise the notion of power anchored in the ideological framework of its polysemous nature. Such progressive elucidation of the concept creates tension between empowerment and domination which is a relevant concern in feminist politics and interpretations in that the specific implication of such reconceptualization is the object of becoming not oppressors, but of becoming liberated that, in the discourse of Malayness is largely problematic as it is always perceived to be antithetical to revitalization of Islam through Malaysian Literature for 'liberalism' in this case, is associated with the rupture of women's sexuality. However, as this paper argues that such kind of writing is not antithesis, but rather an attempt to create a new consciousness, a representational alternative thesis to reshape the socio-political landscape, it is necessary to question: to what extent does liberal sexuality, as a transformational mechanism, in contemporary malay fiction (1) positively mediate the already fragmented and multifaceted state of affairs and (2) empower women? What are the characteristics and quality of such power? Moreover, this paper questions: How does the absence/presence of metaphorical panopticon in the characters of Nooralissa Firdaus and Sara create a female ideological framework that significantly paralyzes stereotypical roles and functions of women in Malay culture? These questions shall be answered through careful and detailed analysis of the central characters in the two short stories.

\section{RESULTS AND DISCUSSIONS}

\section{The New Malay Woman}

Mahathir's Vision 2020, in a very clear sense, is a social policy fabricated to generate national unity and perceptibly new jatidiri bangsa (national identity) (Furlow, 2009). In the 1995 book entitled The Voice of Asia co-authored with Shitaharo Ishihara, who was Tokyo's mayor, in which Mahathir mentions:

In formulating Vision 2020, we had to define what we meant by 'developed country'. Does the term refer simply to a per capita income of at least US\$16,000, or does it also imply stability and solid cultural value? All these factors have to be considered, but it is clear that wealth alone does not constitute development. No country is really developed, for instance, if it has money but no technology. Nor is a country developed, in our sense of the word, if it has money and technology but lacks firm moral values. Many Western societies, for example, are morally decadent. There is diminishing respect for the institutions of the family and marriage, and some even permit same-gender marriages. To us, that is not development. You must maintain cultural and moral values. We do not want to be just a rich country. (Mohamad \& Ishihara, 1996) 
Certainly, Mahathir imagines a Malaysian knowledge-society (K-society) that grandstands money, technology, and moral values. By moral values, he pertinently means the (re)constructed behaviour of the new Malay as a result of Islamic Revivalism. Unlike Western Modernization, 'Mahathir argues that the West has separated religious and secular life and replaced religious values with hedonistic ones like materialism, sensual gratification, and selfishness that are leading the West to an impending collapse' (Furlow, 2009). Comparatively, Jan (2002) believes that behavioural construct is regulated by the desire of society in the preservation of its cultural norms. Some aspects of Malay/sian behaviour that are considered feminine are as follows:

- Not being forthright, assertive, or aggressive;

- Not being blunt in expressing one's view;

- Not causing interpersonal conflict or avoiding ‘loss of face’ (Omar, 1992).

The optimistic construction of the New Malay not only fictionalizes a Malay/sian community, but also detaches the Malay from social irregularities, such as ethnic tensions, caused by modernization itself and secular cultural representations. In a skewed Malay/sian terrain, 'subjectivities are formed and reformed as a result of power practices' (Cooper, 1995). The calculated behaviour of the Malay woman, for instance, is representational but to a great extent, contestable. The short stories would respond to current calculation of the new Malay woman in four planks. First, both women in the stories are independent of paternal control. Nooralissa (The Beloved) in the following passage escapes from the shadow of her famous businessman father:

'You're the only one now, the others have deserted me. Even my mother and father.' And she started sobbing. (9)

The central character is educated and charming, but because she wanted to marry a rich man even out of love, she ended disgraced and confined in solitude by her husband. With the hope of being rescued, the lawyer Nooralissa called to her journalist ex-lover named Johari. Johari narrates the story and portrays Nooralissa or Alissa in his vocabulary from his extensive memory about her. On the other hand, Sara (Sara and the Wedding) was graced by her second cousin Ramli in the following passage:

'See how you looked after your family when your father died. You're baik- so good,' he added, his voice full of awed admiration.

Sara shook her head.

'No, it was nothing. Any daughter would have done it. I just fulfilled my duty.' (95)

After the death of her father, Sara took charge of family negotiations. Her ability of leading a family is just a signification of rule-a property that has always been associated with men. Interestingly, both central characters are lawyers, a masculine profession. The linearity and rationality of the discipline connected to women challenge pre-conceived patriarchal concerns that women are more emotional and often articulates non-consciously (therefore, uncontrolled) generating irrational practice. The text, however, is an essential demystification of gender myth. A. Raksasataya (1968) emphasizes that in a socio-cultural sense, Southeast Asian women 'are oriented toward domestic affairs' and are taught 'to follow, to depend on, and to respect men'. In the context of Islamic Revivalism, for instance, Islam explicitly positions women at men's caprice. Interestingly, this articulation fuels a great deal of dialectical movements whether it exploitative of women or actually a mechanism of empowerment. There is a good deal of clarification on that area in this paper. But certainly, in Karim Raslan's fiction the feminine is not very effeminate anymore. Sara actually became a famous lawyer; known for her diligence and commitment. This brings the second characteristic of new Malay woman, Nooralissa and Sara are both an asset. Thus, the presence of the women is important and functional. In the following passage, Johari's mother actualizes the importance of Malay woman: 


\begin{abstract}
She says that now but at the time she was ecstatic: she told half of Malacca and virtually all of Alor Gajah that I was going out with Alissa after I had brought her home just the once. Within a week she'd already chosen the baju she was going to wear for the bersanding and who was going to be my pengapit, worrying herself half to death, trying to figure out how she would carry herself when talking to Alissa's parents. They're so rich, so sophisticated, she'd say. It wasn't a serious worry, it was more a delicious kind of 'worry', the kind that occupies your mind for hours pleasantly. (16)
\end{abstract}

Obviously, Sara is an asset because she is a famous character. In the same way, Nooralissa is an asset because she hails from a decent and rich family. Needless to say, the social gratification of the central characters is based on the presence of technology. In this case, technology can be referred to the pleasurable concepts that can be attached to the women, like fame and richness. As I follow the framework of Cooper, the social conception that the central characters are assets, whose presence is important to society, is a technological effect that is conceived as the productivity of power. The third characteristic is, of the irreducibility of the woman. The Malay woman is unimaginable, incalculable. Nooralissa dismisses this very powerful line about her being irreducible:

\title{
She had also made me promise that I'd never write about her-a bond that I'd broken almost immediately.
}

'Me? I'm irreducible!' She'd said at the time, laughing as she threw back in my face with an impertinent tilt of her head, a word I'd used only minutes before.

'I can use big words, too, Shukor but that doesn't make me a writer. Besides my life is going to be boring that no one will ever want to write about me. I'll marry well-no, not you, you're too poor. I'll have three children and attend lots of charity teas with all my sisters.

Nooralissa tells Johari that she's irreducible not that she is too rich and beautiful to be written by a monetarily poor journalist like him, but that as a man, writing a woman in his own words is unlikely representational. Klages (2007) discusses poststructuralist feminism which is helpful in understanding Nooralisa's claim on her irreducibility:
[S] ubjects who are further away from the controlling influence of the centre have more play, more 'freedom' to move and to behave as they wish. The capacity to avoid, escape, or evade the structuring rules of the centre of a structure or system is what Lacan and the poststructuralist feminist theorists call jouissance which is the French word for 'orgasm'. The word in poststructuralist terminology means pleasure that is beyond language, beyond discourse, something that can't be expressed in words or in the structure of language, and which in fact is disruptive to that structure. This form of pleasure, or any activity or position that escapes the rules and structures held in place by the Phallus, is specifically feminine pleasure, a feminine jouissance which is unrepresentable in language, and which interrupts representation, disturbs the linear flow of language, and rattles the foundations of the structure of the Symbolic. Thus jouissance can be considered a type of deconstruction, as it shakes up the fixity and stability of the structure of language and puts signifier into play, making them slippery and indeterminate. (Klages, 2007:97)

Helene Cixous enters the debate by first coining the term 'phallogocentric' borrowing Derrida's 'logocentric', 'a term to describe Western culture's preference for speech over language' (Klages, 2007), then ascertains that since the Symbolic Order is phallogocentric and that prosaic writing, such as the texts that are being discussed in this paper, represents the Symbolic Order which is centred on Phallic discourse that ultimately represses the feminine, a clear-cut positioning of the text has to be drawn in this paper. I concede two layers of repression in Karim Raslan's texts that have something to do with Feminist ideals. First, Karim Raslan is not a woman, therefore, an Other in feminine discourse. Second, the text is in prose and not in poetry that it makes jouissance far from 
reach because as Helene Cixous continues, poetry is more likely to accommodate a signifying system that embraces 'play', more fluidity, ambivalence, and multiple meanings.

However, in the context of production and representation of Malay culture, the notion of the 'phallogocentric' talk is always inevitable and is almost invisible in the sense that it is totally tolerated. What I acknowledge as viable is to dissect how Malay culture, as a phallogocentric order, subordinates and represses the feminine. Surely, the text of Karim Raslan is not sufficient to exhaust the enormous 'struggle' of the Malay woman, but it attacks the tension in such an extraordinary, brave, and witty way- through women's sexuality that is commonly perceived as impalpable in Malay sense. What this paper wants to capitalize is that particular strength of the texts. Finally, the central characters exhibit liberal ideology. Nooralissa, in the account of Johari, seemed to be blunt and very assertive. Her character is a special departure from a Malay woman who had been conceived as a shadow of the substance:

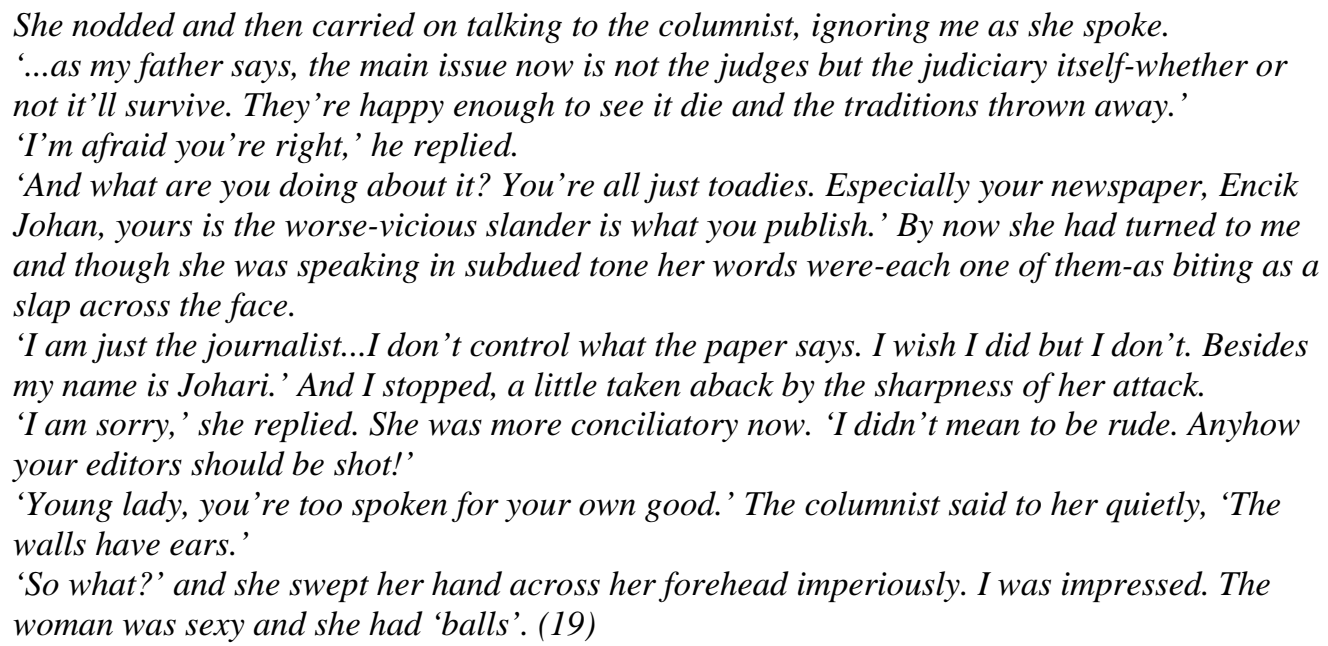

Nooralissa's liberal ideology is characterized primarily by her assertiveness and fearlessness. She commits herself to her strong language that does not eliminate her womanhood. When she criticized the Newspaper which was affiliated with Johari, she accepted subordination when she apologized but never did she recant her words. As a result, she was able to sustain the revered attention of the man. Hence, the new Malay woman is empowered in Karim Raslan's text because she is capable of exerting power. Cooper (1995) argues that any form of resistance implies domination, then resistance requires 'at least a certain ability to impact'. Moreover, structuring systems such as gender and class are strong determinants of empowered subject positions. It is noteworthy to mention that Johari married a woman in lesser image than Nooralissa.

The romanticism of Johari to his past, generally, is a double-edged sword. On one hand, it empowers Nooralissa in a confessional sense because as Johari listens to her, it allows her to execute that social urge to explain and justify. On the other hand, the wife of Johari was silenced in the text that is safe to read as the absence of production of power. What is apparent in the situation is the complex and dynamic relation of Malay women to men. In the same way, Gerhard believes on understanding the limitations of sexual ideologies that controlled women's lives (Hollibaugh, 2002). There was a period in Feminist movement that the phrase 'all women' actually signified always white, straight, and middle to upper class. Thus, I argue that Malay woman's notion of power is always determined by individual subject positions and not by universal concept of resistance. Sara, on the other hand, faces a larger struggle in realizing power. Unlike Nooralissa, Sara was described as plump, homely, and sweaty. So she finds herself not attractive at all and that predicament was a considerable mishap in her life since Malay culture asserts that marriage of malay woman is a non-negotiable direction. Tong \& Turner (2008) believes that 'the pressure against being single in a society where 
marriage was regarded as a compulsory norm was the main cause' for marriage even if a modernizing society such as Malaysia 'brings about opportunities for them to pursue their self-actualization and to choose their lifestyles'. Definitely, Sara felt the pressure and to some length, ostracism of her family in the following passage:

\begin{abstract}
Here she was dashing about, worrying about her sister's wedding when, in actual fact, the mere thought of it made her feel unwanted and shamed. Why should she care that Shahnaz's pelamin was uneven? It wasn't her bersanding. She was the one who was expected to grow old and useless on a steady diet of loneliness and solitude. They didn't seem to care that she supported half the family, that she had her own successful legal practice, that outside the home she was respected and admired. Damn them, they didn't care-she was just the fat-fat one who was still unmarried. (92)
\end{abstract}

Indubitably, the passage lets non-Malays know that the concept of family is a disciplinary structure, too. At this point, I feel it essential to explain what the state really means. Cooper (1995) maintains that the state has a multiple and contested identity in that it is 'contingently articulated, multifaceted phenomena with no fixed form, essence, or core'. But she suggests charting a middle course between an approach which argues that the state is definable and another promoting discursive relativism. I particularly want to elaborate on the frameworks positioning of the concept of the state because I believe that there is a significant relationship between the concept of the state and the concept of family, as both function in punitive terms. I argue that the Malay concept of family functions as a mechanism through which the state continuously operates. It appears to be that Malay family serves as a condensed manifestation of economic, racial and gendered power that legitimate even personal views and subject positions. What interests me is the fact that the central government restructuring becomes unendingly dynamic because it is already embedded in Malay culture to be egalitarian, thus, communal. Sara overcomes her struggle slightly because of dispassion, but largely of the desire for power.

\title{
CONCLUSION
}

\section{Panoptic Gaze and Female Transcendence}

As the story of Nooralissa comes from the heavy memory and perspective of Johari, readers are given the chance to scrutinize the mind or memory of Johari. This is very interesting to me because his account is partially reflecting the truth, i.e. factual, but largely truthful. Johari's account is centred on the perspectival premise that Nooralissa loves to be worshipped, as in:

'Tell me you love me, shukor. You're a writer, a man who uses words. Use them to worship me.'

And Johari loves to worship, as in:

Whatever I professed to have felt and thought about her in my poetry, I saw that in reality I had hardly bothered myself with the woman. Alissa, my Alissa, had been nothing more than a resource.

Interestingly, both of them wanted a fictional worship, something that is abstract, written, and shapeless. Specifically, there are three positions that, I argue, as the cornerstone of her liberal ideology. First, she is a rule. Second, she is foreign, eerie, and even unearthly to Johari. Lastly, she acknowledges sexual intercourse as part of her.

Johari recounts that one day, Nooralissa left her 'one day with nothing more than a crumpled selandang and a stash of her contraceptive pills' (Raslan, 1996). 'The essential task imposed on 
bodies in society' is simplified in the idea of 'government of sex' (Wilder, 1998). In Malay culture, 'family planning ideology' is viewed 'as ultimately a threat to' Malays' 'national survival' (Ong, 1990). The state, i.e. central government, encourages Malay families to have many children as a good way of increasing wealth and ensuring success of the race. Ong (1990) believes that Family Planning challenges two key elements of masculinity: (1) a man's regulation over his wife's sexuality and (2) a man's ability to raise children . In this light, malay masculinity is derived in twofold: one is from his power to control feminine presence and the other is through economic prowess. Johari's masculinity is totally destroyed by Nooralisa's transgression. What keeps me speculating is the fact that Johari maintained his passion for Nooralisa despite her disobedience to Malay custom.

In the days before she disappeared from my life, she had always been 'sunny'. And I don't mean 'sunny' in Malaysian sense-our sun cracks the back of your head like a shovel. She was 'sunny' in the New Zealand sense of the word (or at least what I imagine it to be since I've never been to New Zealand). She was bright and yet soft; warm and delicate-like Salem 'Cool Country' ads that they repeat on the television hour after hour. I remember thinking that fate had really smiled on her: she was beautiful, she was rich and she was lovely. (13)

Johari perceives Nooralissa as somebody from the outside, something foreign, almost unearthly. He imagines her in strictly ideal and poetic terms. Johari's perception of Nooralissa is like a fictive sensation that he actually becomes the mirror which she uses to worship her beauty (Schroeder, 1988).

The battle seemed so important then, the sort of thing that would have kept Alissa and I up until the early hours of the morning arguing: she was as passionate in bed as she was in her arguments. (18)

Nooralissa's treatment to sex as a non-private affair is a political and cultural strategy to liberate sexuality. Cooper (1995) argues that the 'sexualisation of everyday life and the rejection that sexual politics as an exclusive concern of a young, educated elite undermines social inequality' (4). But for Johari, the liberation of Nooralissa's sexuality is detrimental. Machin \& Thornborrow (2006) argue that the primary function of Discourse of sex is to 'challenge previous, more conservative regimes'. Indeed, Malay woman's power is not presented in 'public social domain, but in fictionalized spaces' with the presence of fictionalized masculinity. Johari's active imaginative eroticism was countered by Nooralissa's loveless attachment. Fuchs (1980) discusses the advantageous points of loveless eroticism:

\begin{abstract}
The erotic may include, but certainly need not include, love. A lesson that de Beauvoir teaches well-particularly in her novels-is the evil of the dependency of woman and, relatedly, how perfect a medium the emotion of love is for this. She finds the woman in love a necessarily conflicted human being, first because of the nature of love itself, and second because of the ease with which love becomes a real trap for a woman, to the extent that it provides her with a reason for being satisfied with less than freedom.(304-305)
\end{abstract}

Johari's character was constructed based on feminine passion so he continuously thinks that Nooralissa would be his, just with a need of 'little editing'. Simone de Beauvoir (1980) suggests that woman may overcome erotic passivity that man and culture require of her by 'the creation, within heterosexual couples, of a reciprocal relationship between female and male, in order that woman's subjectivity be permitted and acknowledged, as her body is desired'. Such desire was the source of her power. Her total rejection, as masochistic compulsion to him, inspired an idealization of a muse free from any regulation of the state or anybody, because even the maker couldn't totally understand the fictive creation whose power was nevertheless fictive as well. 


\section{REFERENCES}

Abu Bakar, M. (1981). Islamic revivalism and the political process in Malaysia. Asian Survey, 21(20), 1040-1059.

Avelling, H. (2000). Shahnon Ahmad: Islam, power and gender. Bangi: Penerbit Universiti Kebangsaan Malaysia.

Banks, D. (1990). Resurgent Islam and Malay rural culture: Malay novelists and the invention of culture. American Ethnologist, 17(3), 531-548.

Ben Joned, S. (1994). As I please, London: Skoob Books.

Carmody, M. (2010). Beauty without borders. Overland, 200, 24-28.

Camroux, D. (1996). State responses to Islamic resurgence in Malaysia: Accommodation, co-option, and confrontation. Asian Survey, 36(9), 852-868.

Cooper, D. (1995) Power in struggle: Feminism, sexuality, and the state. Washington Square, New York, NY: New York University Press.

De Beauvoir, S. (1952). The second sex. New York, NY: Knopf.

Fuchs, J. (2004). Female Eroticism in The second sex. Feminist Studies, 6(2), 304-313.

Furlow, C. A. (2009). Malaysian modernities: Cultural politics and the construction of Muslim technoscientific identities. Anthropological Quarterly, 82(1), 197-228.

Hollibaugh, A. (2002) The Limits of Liberation: book review, The Women's Review of Books (19) 8, p22

Houben, V. J.H. (2003). Southeast Asia and Islam. Annals of the American Academy of Political and Social Science, 588, 149-170.

Jan, J. M. (2002). Interpretation of gender in a Malaysian novel: The case of Salina. Pertanika J. Soc. Sci. \& Hum., 10(2), 143-152.

Klages, M. (2007). Literary Theory: A Guide for the Perplexed. Continuum.

Machin, D., \& Thornborrow, J. (2006). The depoliticisation of agency: sex as power in women's magazines. Social Semiotics 16 (1), 173-188.

Metzger, L. (1991). Continuity and change in the itinerary of the Malay novelist, Shahnon Ahmad. Journal of Southeast Asian Studies, 22(1), 63-74.

Mohamad, M., \& Ishihara, S. (eds). (1996) The Voice of Asia: Two Leaders Discuss the Coming Century. Trans. by Frank Baldwin. New York: Kodansha.

Mutalib, H. (1990). Islamic revivalism in ASEAN states: political implications. Asian Survey, 30(9), 877-891. 
Omar, A. H. (1992). The linguistic scenery in Malaysia. Kuala Lumpur: Dewan Bahasa dan Pustaka.

Ong, A. (1990). State versus Islam: Malay families, women’s bodies, and the body politic in Malaysia. American Ethnologist, 17(2), 258-276.

Raslan, K. (1996). Heroes and other stories. Singapore \& Kuala Lumpur: Times Books International.

Raksasataya, A. (1968). The political role of Southeast Asian women. The ANNALS of the American Academy of Political and Social Science, 375(86), 86-90.

Schroeder, N. (1988). Feminine sensationalism, eroticism, and self-assertion: M.E. Braddon and Ouida. Tulsa Studies in Women's Literature, 7(1), 87-103.

Shieth, F. (2007). Unruly Muslim women and threats to liberal culture. Peace Review: A Journal of Social Justice, 18, 455-463.

Therborn, G. (2003). Entangled modernities. European Journal of Social Theory, 6(293), 293-305.

Timmerman, C. (2000). Muslim women and nationalism: The power of the image. Current Sociology, 48(15), 15-27.

Tong, J. K. C. \& Turner, B. S. (2008). Women, piety, and practice: A study of women and religious practice in Malaysia. Contemporary Islam, 2, 41-59.

Wilder, W.D. (1998). Bodies in the east: Cosmic images in Malay tradition. Cultural Geographies, 5(2), 167-185.

Zizek, S. (2008)._Violence. New York, NY: Picador. 